\title{
ANTI-HYPERLIPIDEMIC ACTIVITY OF METHANOLIC EXTRACT OF BOESENBERGIA PANDURATA (FINGER ROOT) IN EXPERIMENTAL INDUCED HYPERCHOLESTROLEMIC SPRAGUE DAWLEY RATS
}

\author{
SANTOSH FATTEPUR ${ }^{1 *}$, KIRAN CHANABASAPPA NILUGAL ${ }^{1}$, RANYA RAJENDRAN ${ }^{1}$, FADLI ASMANI ${ }^{2}$, EDDY YUSUF ${ }^{2}$ \\ ${ }^{1}$ Department of Pharmacology, School of Pharmacy, Management and Science University Shah Alam, Selangor, Malaysia. ${ }^{2}$ Department of \\ Clinical pharmacy, School of Pharmacy, Management and Science University Shah Alam, Selangor, Malaysia. Email: santoshsrf@yahoo.com
}

Received: 22 December 2018, Revised and Accepted: 19 April 2018

ABSTRACT

Objective: Hyperlipidemia is one of the risk factors that contribute to the prevalence of coronary heart diseases and antihyperlipidemic agents, such as statin, was used to treat hyperlipidemia as a current therapy. Boesenbergia pandurata has not been exploited for antihyperlipidemic effect. Hence, this study aims to screen for the antihyperlipidemic activity of methanolic extracts of B. pandurata rhizomes (BPR extracts) in hypercholesterolemiainduced Sprague-Dawley rats.

Methods: BPR extracts were prepared using the maceration method with $1500 \mathrm{ml}$ of $80 \%$ methanol at room temperature for about 7 days. A toxicity study was carried out based on OECD guidelines. Hypercholesterolemia was induced by $6 \%$ lard oil, $2 \%$ of cheese, and egg yolks. Two different doses of BPR extracts, 200 and $400 \mathrm{mg} / \mathrm{kg}$, were used to screen for antihyperlipidemic effect. Histopathological study was carried out in the liver. The results were evaluated for the statistically significant difference by using the one-way ANOVA followed by post hoc Dunnett test.

Results: No mortality was witnessed even till $2 \mathrm{~g} / \mathrm{kg}$. Only $400 \mathrm{mg} / \mathrm{kg}$ of $B P R$ extracts statistically reduced in total cholesterol (p<0.05), low-density lipoprotein-cholesterol $(\mathrm{p}<0.05)$ and an increase in high-density lipoprotein-cholesterol $(\mathrm{p}<0.05)$ when compared to the positive control. BPR extracts $(400 \mathrm{mg} / \mathrm{kg})$ showed less enlargement of lipid droplets as compared to positive control.

Conclusion: $B P R$ extracts can be a promising medicinal plant for treating hyperlipidemia in underdeveloped countries.

Keywords: Anti-hyperlipidemia, Hypercholesterolemia, Statins, Finger root (Boesenbergia pandurata).

(c) 2018 The Authors. Published by Innovare Academic Sciences Pvt Ltd. This is an open access article under the CC BY license (http://creativecommons. org/licenses/by/4. 0/) DOI: http://dx.doi.org/10.22159/ajpcr.2018.v11s3.29962

\section{INTRODUCTON}

Hyperlipidemia is known as a condition of increased level of serum total cholesterol (TC), low-density lipoprotein (LDL), very LDL (VLDL), and reduced high-density lipoprotein (HDL). Hyperlipidemia has been sorted as one of the high-risk factors that lead to the prevalence and severity of coronary heart diseases [1]. The desired level of TC is $<200 \mathrm{mg} / \mathrm{dL}$, LDL is $<130 \mathrm{mg} / \mathrm{dL}$, triglycerides is $<120 \mathrm{mg} / \mathrm{dL}$, and HDL for men is $>40 \mathrm{mg} / \mathrm{dL}$ while for women is $>50 \mathrm{mg} / \mathrm{dL}$. Hyperlipidemia can be categorized into two groups which are the primary and the secondary. The primary hyperlipidemia can be further divided into five types. The second type is better known as the secondary causes of hyperlipoproteinemia [2].

In modern globalization era, there is almost treatment for all diseases including treatments for hyperlipidemia. Many antihyperlipidemia therapies such as statin and fibrates that aid in correcting the altered blood lipid profile by hindering the formation of cholesterol and by improving the clearance of triglycerides rich lipoproteins [3]. Many drugs used for the treatment are found to be associated with side effects when used. These may lead to hyperuricemia, diarrhea, nausea, myositis, gastric irritation, flushing, dry skin, and also abnormal liver function [4]. Natural sources are believed to have lesser side effects than the available therapy in the market. Therefore, it is important to find other essential materials from natural sources which are low in toxic, low in cost, and provides better safety and efficacy on a longterm usage. It has been for centuries that natural products from a plant source are used to cure various ailments [5].
Many researches have been done on Boesenbergia pandurata which is profoundly found all over Indonesia, Thailand, and Malaysia. The plant extract has proven antibacterial, antifungal, anti-inflammatory, analgesic, antipyretic, antispasmodic, antitumor, and insecticidal activities [6]. Till date, it lacks antihyperlipidemic activity. Therefore, the study has been conducted to screen the antihyperlipidemic properties of B. pandurata rhizomes (BPR) extracts in rats.

\section{MATERIALS AND METHODS}

Collection of plant materials

The fresh rhizomes of B. pandurata were collected from local area in Johor Bahru, Malaysia, and got authenticated from FRIM (Forest Research Institute Malaysia).

Maintenance of animals and approval of protocol

Healthy Sprague-Dawley (SD) rats weighing between 100 and $150 \mathrm{~g}$ were obtained from the local vendor and placed in the polypropylene cages maintained at $25 \pm 2^{\circ} \mathrm{C}$ in Management and Science University animal house. Throughout the study, they are maintained on standard pallet and water ad libitum. Institutional Animal Ethical Clearance was obtained before the study.

\section{Preparation of extract}

The rhizomes of the B. pandurata were sliced, shade-dried, and powdered using the mechanical grinder. $500 \mathrm{~g}$ of the powdered rhizomes was macerated with $1500 \mathrm{ml}$ of $80 \%$ methanol at room temperature for 7 days, and the final product was filtered using a muslin cloth and filter paper. The extract was concentrated to dryness 


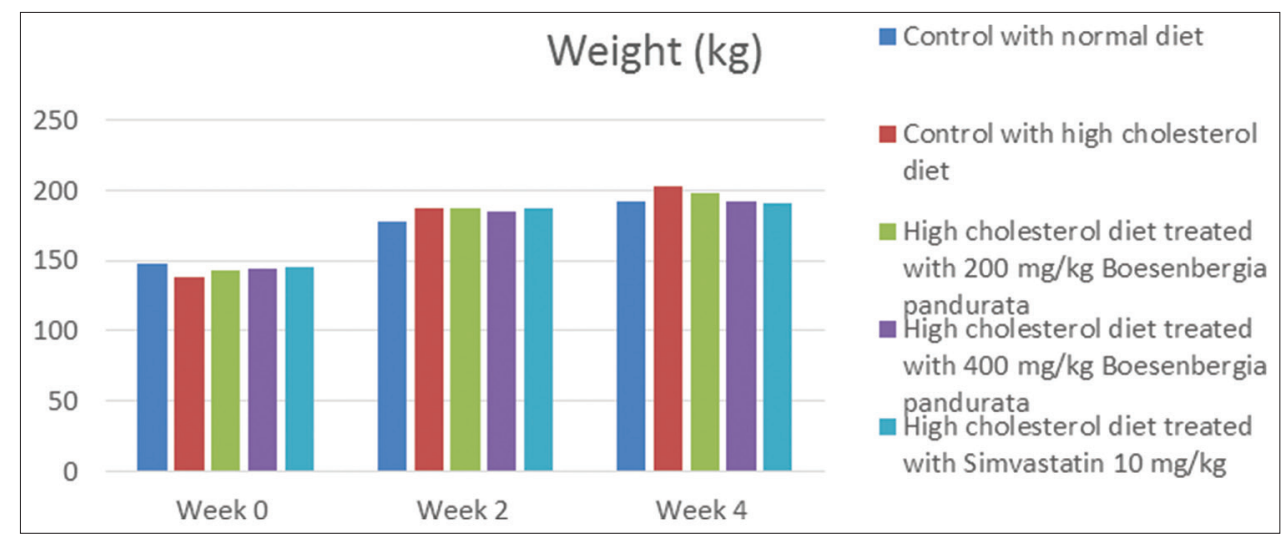

Fig. 1: Antihyperlipidemia effect of Boesenbergia pandurata rhizomes extract $200 \mathrm{mg} / \mathrm{kg}$ and $400 \mathrm{mg} / \mathrm{kg}$ in hyperlipidemia-induced rats. The values of weight are expressed as mean \pm SEM of six rats

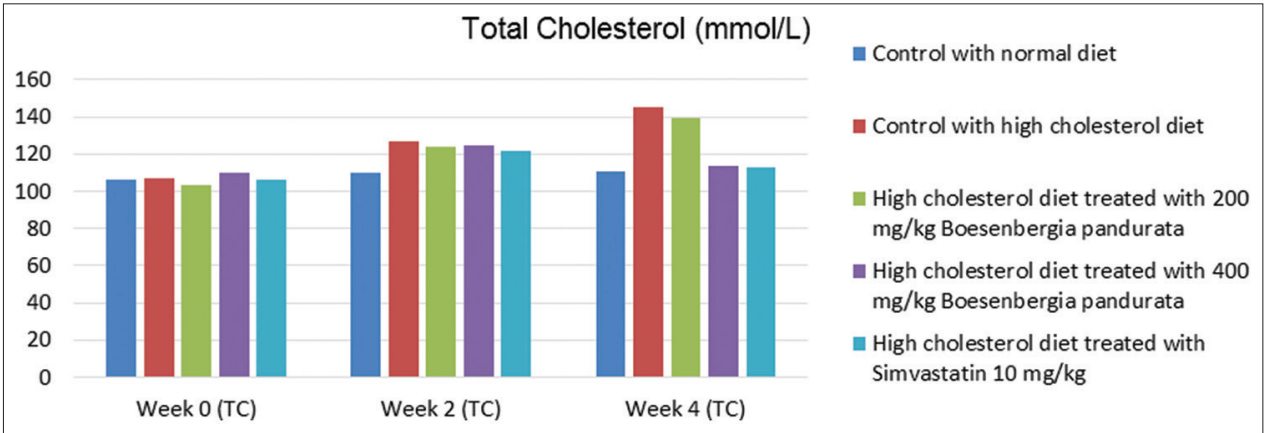

Fig. 2: Antihyperlipidemic effect of Boesenbergia pandurata rhizomes extract $200 \mathrm{mg} / \mathrm{kg}$ and $400 \mathrm{mg} / \mathrm{kg}$ in hyperlipidemia-induced rats. The values of total cholesterol are expressed as mean \pm SEM.

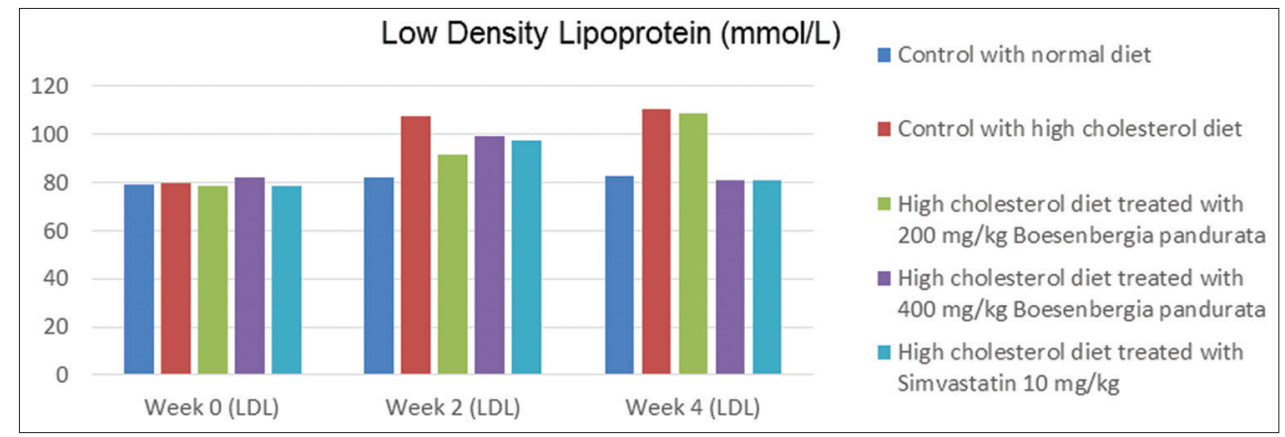

Fig. 3: Antihyperlipidemic effect of Boesenbergia pandurata rhizomes extract $200 \mathrm{mg} / \mathrm{kg}$ and $400 \mathrm{mg} / \mathrm{kg}$ in hyperlipidemia-induced rats. The values of low-density lipoprotein are expressed as mean \pm SEM

under reduced pressure and controlled temperature $\left(40-50^{\circ} \mathrm{C}\right)$ in rotatory evaporator to remove the methanol. The brownish extract was scrapped out and weighed to quantify the yield value and also other organoleptic properties. The yielded BPR extract was kept at $4^{\circ} \mathrm{C}$ (cold room) until further use [7].

\section{Toxicity study}

A single dose of $500 \mathrm{mg} / \mathrm{kg}, 1 \mathrm{~g} / \mathrm{kg}$, and $2 \mathrm{~g} / \mathrm{kg}$ of $B P R$ extract was given by intragastric intubation by gavage needle to $S D$ rats $(n=3)$. The animals were observed for mortality and toxicity signs for 14 days. The animals were observed individually at least once during the first $30 \mathrm{~min}$, periodically during the first $4 \mathrm{~h}$, and daily thereafter, for a total of 14 days.

\section{Experimental design (high-cholesterol diet-induced} hyperlipidemia in rats)

The animals were divided into five groups $(\mathrm{n}=6)$ as follows. Group 1 : Normal control rats fed with normal diet for 4 weeks; Group 2: Animals fed with high-cholesterol diet for 4 weeks; Group 3: Animals fed with high-cholesterol diet for 4 weeks. During the last 2 weeks, $200 \mathrm{mg} / \mathrm{kg}$ of $B P R$ extract was administered daily by intragastric intubation; Group 4: Animals fed with high-cholesterol diet for 4 weeks. During the last 2 weeks, $400 \mathrm{mg} / \mathrm{kg}$ of $B P R$ extract was administered daily by intragastric intubation; and Group 5: Animals fed with high-cholesterol diet for 4 weeks. During the last 2 weeks, the reference standard drug Simvastatin $(10 \mathrm{mg} / \mathrm{kg})$ was administered daily by intragastric intubation.

\section{Preparation of high-cholesterol diet}

Eggs and high-cholesterol cheese were procured from local market at Klang Valley, Malaysia. The lard oil was prepared using rendering method where mutton fats were bought from Masai, Johor Market, and chopped to fine cubes. These fat cubes were placed in a large stockpot and heated slowly, delicately over the medium heat. The fat was stirred at regular interval for $30 \mathrm{~min}$. The high-cholesterol diet was prepared by mixing $60 \mathrm{ml}$ of melted lard oil, with 2 egg yolks, and $20 \mathrm{ml}$ of melted cheese. These ingredients were mixed at mild heat water bath to prevent solidification 
of oil and cheese at room temperature. This high-cholesterol diet was fed to the SD rats for 4 weeks according to their body weight by using gavage needle. Each rat was weighed and received $20 \mathrm{ml} / \mathrm{kg}$ of this semisolid high-cholesterol diet twice daily (morning and evening) [8].

\section{Biochemical analysis}

The enzymatic kit was used to assay the TC, LDL-cholesterol, and HDLcholesterol. The blood biochemical analysis was done by using ACON MISSION Cholesterol meter [9].

\section{Histopathological assessment}

The liver sections of the SD rats were fixed in $10 \%$ formaldehyde, dehydrated in gradual ethanol (50-100\%), cleared in xylene, and embedded in paraffin. Sections ( $4-5 \mu \mathrm{m}$ thick) were prepared and stained with hematoxylin and eosin (HE) dye and observed under a microscope.

\section{Statistical analysis}

The results were evaluated for the statistically significant difference using the one-way ANOVA followed by post hoc Dunnett test using SPSS software version 24 . A statistically significant difference was accepted at the level of $\mathrm{p}<0.05$.

\section{RESULTS}

\section{Toxicity study}

There were no toxic symptoms or mortality was observed or recorded in all the animals that have been given with $500 \mathrm{mg} / \mathrm{kg}, 1 \mathrm{~g} / \mathrm{kg}$, and $2 \mathrm{~g} / \mathrm{kg}$ of the BPR extract (Figs. 1-5).

\section{Histopathological result}

Histopathological examinations were performed on the liver to assess whether the tissue have been damaged or not. The results indicated that rats treated with high cholesterol diet and also the rats treated with high cholesterol diet treated with $200 \mathrm{mg} / \mathrm{kg}$ BPR extract showed swelling in liver cells and also steatosis. However the animals treated high cholesterol diet treated with $400 \mathrm{mg} / \mathrm{kg}$ BPR extract showed reduction in swelling and steatosis. The results are shown in the Table 6.

\section{DISCUSSION}

It is well known that nutrition plays an essential role in causing hyperlipidemia and atherosclerosis. Fat diet was used in the study

Table 1: Antihyperlipidemic effect of BPR extracts $200 \mathrm{mg} / \mathrm{kg}$ and $400 \mathrm{mg} / \mathrm{kg}$ in hyperlipidemia-induced rats

\begin{tabular}{|c|c|c|c|c|}
\hline \multirow[t]{2}{*}{ Groups } & \multirow[t]{2}{*}{ Treatment } & \multicolumn{3}{|l|}{ Weight (kg) } \\
\hline & & Week 0 & Week 2 & Week 4 \\
\hline I & Normal standard diet & $147.75 \pm 1.62$ & $177.68 \pm 1.67$ & $192.56 \pm 1.49$ \\
\hline II & High-cholesterol diet & $138.26 \pm 1.87$ & $187.58 \pm 1.20$ & $202.60 \pm 1.86$ \\
\hline III & High-cholesterol diet treated with $200 \mathrm{mg} / \mathrm{kg}$ BPR extract & $142.49 \pm 3.18$ & $187.83 \pm 1.05$ & $198.13 \pm 1.91$ \\
\hline IV & High-cholesterol diet treated with $400 \mathrm{mg} / \mathrm{kg}$ BPR extract & $143.63 \pm 1.54$ & $185.41 \pm 1.39$ & $191.49 \pm 1.60$ \\
\hline V & High-cholesterol diet treated with simvastatin $(10 \mathrm{mg} / \mathrm{kg})$ & $145.69 \pm 1.50$ & $187.45 \pm 2.61$ & $190.90 \pm 1.51$ \\
\hline
\end{tabular}

The values of weight are expressed as mean \pm SEM. BPR: Boesenbergia pandurata rhizomes

Table 2: Antihyperlipidemic effect of BPR extracts $200 \mathrm{mg} / \mathrm{kg}$ and $400 \mathrm{mg} / \mathrm{kg}$ in hyperlipidemia-induced rats

\begin{tabular}{|c|c|c|c|c|}
\hline \multirow[t]{2}{*}{ Groups } & \multirow[t]{2}{*}{ Treatment } & \multicolumn{3}{|l|}{ TC mmol/L } \\
\hline & & Week 0 & Week 2 & Week 4 \\
\hline I & Normal standard diet & $106.02 \pm 2.24$ & $109.59 \pm 2.47$ & $110.54 \pm 2.11$ \\
\hline III & High-cholesterol diet treated with $200 \mathrm{mg} / \mathrm{kg} \mathrm{BPR} \mathrm{extract}$ & $103.46 \pm 1.47$ & $123.86 \pm 2.18$ & $139.34 \pm 3.52^{b}$ \\
\hline IV & High-cholesterol diet treated with $400 \mathrm{mg} / \mathrm{kg} \mathrm{BPR} \mathrm{extract}$ & $110.13 \pm 1.58$ & $124.46 \pm 2.48$ & $113.42 \pm 2.11^{\mathrm{a}}$ \\
\hline V & High-cholesterol diet treated with simvastatin $(10 \mathrm{mg} / \mathrm{kg})$ & $106.33 \pm 1.73$ & $121.83 \pm 3.89$ & $112.67 \pm 4.57^{\mathrm{a}}$ \\
\hline
\end{tabular}

The values of TC are expressed as mean \pm SEM. ${ }^{\mathrm{a}} \mathrm{p}<0.05$ compared with positive control. TC: Total cholesterol, BPR: Boesenbergia pandurata rhizomes

Table 3: Antihyperlipidemic effect of BPR extract $200 \mathrm{mg} / \mathrm{kg}$ and $400 \mathrm{mg} / \mathrm{kg}$ in hyperlipidemia-induced rats

\begin{tabular}{|c|c|c|c|c|}
\hline \multirow[t]{2}{*}{ Groups } & \multirow[t]{2}{*}{ Treatment } & \multicolumn{3}{|c|}{ LDL mmol/L } \\
\hline & & Week 0 & Week 2 & Week 4 \\
\hline I & Normal standard diet & $79.37 \pm 2.16$ & $82.33 \pm 1.35$ & $82.74 \pm 0.93$ \\
\hline II & High-cholesterol diet & $79.53 \pm 2.29$ & $107.75 \pm 3.19$ & $110.56 \pm 4.17$ \\
\hline III & High-cholesterol diet treated with $200 \mathrm{mg} / \mathrm{kg}$ BPR extract & $78.24 \pm 2.26$ & $91.63 \pm 3.31$ & $108.44 \pm 1.65^{b}$ \\
\hline IV & High-cholesterol diet treated with $400 \mathrm{mg} / \mathrm{kg} \mathrm{BPR} \mathrm{extract}$ & $81.80 \pm 2.26$ & $99.36 \pm 5.30$ & $81.10 \pm 1.23^{\mathrm{a}}$ \\
\hline V & High-cholesterol diet treated with Simvastatin $(10 \mathrm{mg} / \mathrm{kg})$ & $78.45 \pm 2.26$ & $97.33 \pm 2.31$ & $81.08 \pm 2.52^{\mathrm{a}}$ \\
\hline
\end{tabular}

The values of LDL are expressed as mean \pm SEM; ${ }^{\mathrm{a}} \mathrm{p}<0.05$; ${ }^{\mathrm{b}}>0.05$ compared with positive control. LDL: Low-density lipoprotein, BPR: Boesenbergia pandurata rhizomes

Table 4: Antihyperlipidemia effect of BPR extract a $200 \mathrm{mg} / \mathrm{kg}$ and $400 \mathrm{mg} / \mathrm{kg}$ in hyperlipidemia-induced rats

\begin{tabular}{|c|c|c|c|c|}
\hline \multirow[t]{2}{*}{ Groups } & \multirow[t]{2}{*}{ Treatment } & \multicolumn{3}{|l|}{ LDL mmol/L } \\
\hline & & Week 0 & Week 2 & Week 4 \\
\hline I & Normal standard diet & $12.46 \pm 0.89$ & $12.94 \pm 0.90$ & $12.60 \pm 0.92$ \\
\hline II & High-cholesterol diet & $12.60 \pm 1.23$ & $12.04 \pm 1.08$ & $11.49 \pm 1.07$ \\
\hline III & High-cholesterol diet treated with $200 \mathrm{mg} / \mathrm{kg}$ BPR extract & $12.67 \pm 0.97$ & $12.95 \pm 1.14$ & $11.28 \pm 1.32^{\mathrm{b}}$ \\
\hline IV & High-cholesterol diet treated with $400 \mathrm{mg} / \mathrm{kg}$ BPR extract & $12.08 \pm 1.26$ & $12.43 \pm 1.20$ & $15.84 \pm 1.09^{\mathrm{a}}$ \\
\hline V & High-cholesterol diet treated with simvastatin $(10 \mathrm{mg} / \mathrm{kg})$ & $12.25 \pm 1.03$ & $12.19 \pm 0.92$ & $16.97 \pm 0.98^{\mathrm{a}}$ \\
\hline
\end{tabular}


Table 5: Antihyperlipidemia effect of BPR extracts $200 \mathrm{mg} / \mathrm{kg}$ and $400 \mathrm{mg} / \mathrm{kg}$ in hyperlipidemia induced rats

\begin{tabular}{lllll}
\hline Groups & Treatment & \multicolumn{3}{l}{$\begin{array}{l}\text { Percentage increase (+) or decrease (-) of lipid values } \\
\text { at week 4 }\end{array}$} \\
\cline { 3 - 5 } & & TC & LDL & HDL \\
\hline I & Normal standard diet & $110.54 \pm 2.11$ & $82.74 \pm 0.93$ & $12.60 \pm 0.92$ \\
II & High-cholesterol diet & $145.42 \pm 2.37$ & $110.56 \pm 4.17$ & $11.49 \pm 1.07$ \\
III & High-cholesterol diet treated with $200 \mathrm{mg} / \mathrm{kg} \mathrm{BPR} \mathrm{extract}$ & $139.34 \pm 3.52$ & $108.44 \pm 1.65$ & $13.28 \pm 1.32$ \\
& & $(-4.18 \%)$ & $(-1.92 \%)$ & $(+15.58 \%)$ \\
IV & High-cholesterol diet treated with $400 \mathrm{mg} / \mathrm{kg} \mathrm{BPR} \mathrm{extract}$ & $113.42 \pm 2.11$ & $87.10 \pm 1.23$ & $15.84 \pm 1.09$ \\
& & $(-22.01 \%)$ & $(-21.22 \%)$ & $(+37.86 \%)$ \\
V & High-cholesterol diet treated with Simvastatin $(10 \mathrm{mg} / \mathrm{kg})$ & $112.67 \pm 4.57$ & $81.08 \pm 2.52$ & $16.97 \pm 0.98$ \\
& & $(-22.52 \%)$ & $(-26.66 \%)$ & $(+47.69 \%)$ \\
\hline
\end{tabular}

The values of percentage increase and decrease in the lipid values at the last week with reference to the positive control are shown below. BPR: Boesenbergia pandurata rhizomes, LDL: Low-density lipoprotein, HDL: High-density lipoprotein, TC: Total cholesterol

Table 6: Histopathological results of the liver of rats with normal diet, high-cholesterol diet and high-cholesterol diet with BPR extracts $200 \mathrm{mg} / \mathrm{kg}$ and $400 \mathrm{mg} / \mathrm{kg}$ in hyperlipidemia-induced rats

\begin{tabular}{|c|c|}
\hline Groups & Histopathological results \\
\hline Normal standard diet & High-cholesterol diet \\
\hline 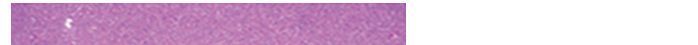 & \\
\hline Liver cell is normal & Liver cells swell with steatos \\
\hline High-cholesterol diet treated with $200 \mathrm{mg} / \mathrm{kg} B P R$ extract & \\
\hline
\end{tabular}

High-cholesterol diet treated with $400 \mathrm{mg} / \mathrm{kg} B P R$ extract Reduction in the swelling of liver cells and reduction in steatosis

Liver cells swell with steatosis

High-cholesterol diet treated with Simvastatin $(10 \mathrm{mg} / \mathrm{kg})$

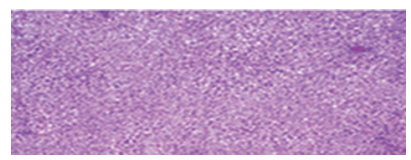

Reduction in the swelling of liver cells, reduction in steatosis, and restoration in the liver tissue morphology

BPR: Boesenbergia pandurata rhizomes

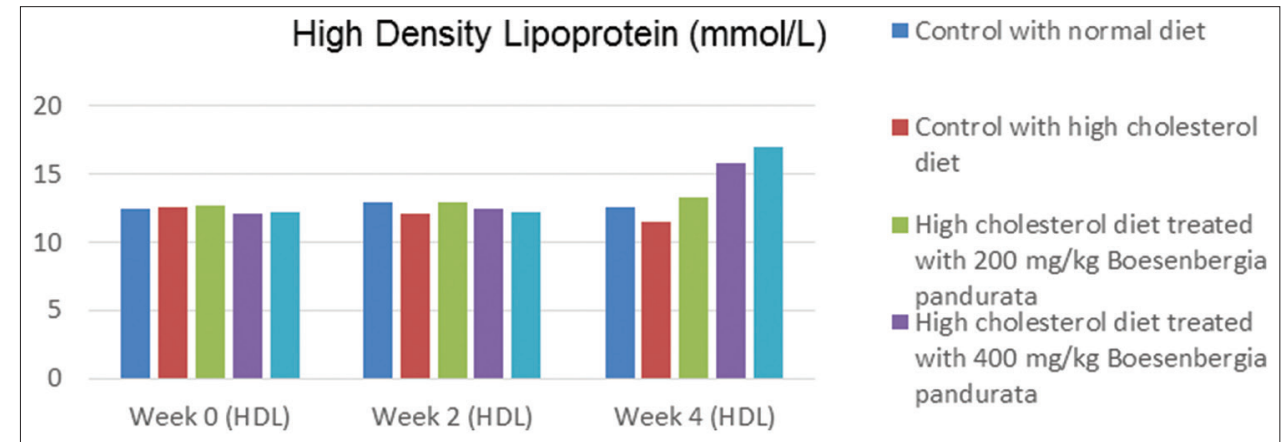

Fig. 4: Antihyperlipidemia effect of Boesenbergia pandurata rhizomes extract $200 \mathrm{mg} / \mathrm{kg}$ and $400 \mathrm{mg} / \mathrm{kg}$ in hyperlipidemia-induced rats. The values of high-density lipoprotein are expressed as mean \pm SEM

which contains some of the common ingredients in our daily. Highcholesterol diet will encourage the rate of cholesterol formation. Moreover, this can also lead to the elevation of serum LDL [8]. It is well known that an increased level of serum LDL-cholesterol will result in an increased threat for the development of atherosclerosis. In the opposite, an increase HDL-cholesterol levels will have a defensive role in the coronary artery disease [5]. Simvastatin is a potent HMG-CoA reductase inhibitor that has the ability to reduce plasma cholesterol levels in hypercholesterolemia patients. Rats treated with Simvastatin showed a marked reduction in all serum lipoproteins and increase in HDL level as compared with high-cholesterol diet group.

No toxic symptoms or mortality was observed or recorded in all the rats that have been given $500 \mathrm{mg} / \mathrm{kg}, 1 \mathrm{~g} / \mathrm{kg}$, and $2 \mathrm{~g} / \mathrm{kg}$ of $B P R$ extract. The 


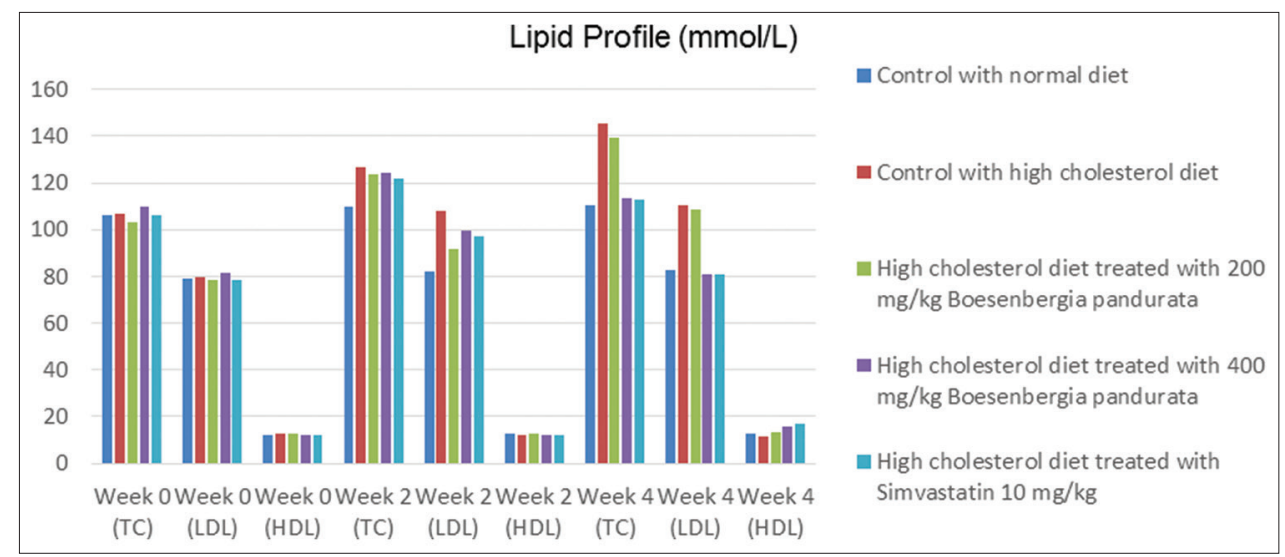

Fig. 5: Antihyperlipidemia effect of Boesenbergia pandurata rhizomes extracts $200 \mathrm{mg} / \mathrm{kg}$ and $400 \mathrm{mg} / \mathrm{kg}$ in hyperlipidemia-induced rats. The values of percentage increase and decrease in the lipid values at the last week with reference to the positive control are shown below

antihyperlipidemia study was conducted by measuring the body weight, and lipid parameters such as TC, LDL, and HDL by using the lipid kits before the study (week 0), during the study (week 2), and also after the study (week 4). The percentage of lipid-lowering was also calculated on the $4^{\text {th }}$ week which is at the end of the study. The results obtained from the study were shown in Tables 1-6. Based on the observation, it shows there is a significant increase in the body weight of animals after inducing hypercholesterolemia in the rats. From the study, it showed that the administration of $B P R$ extract at the dose of $200 \mathrm{mg} / \mathrm{kg}$ does not significantly reduce the high-cholesterol levels of the rats, while the administration at the dose of $400 \mathrm{mg} / \mathrm{kg}$ does significantly reduce the highcholesterol levels of the rats when compared to the positive control group.

From the results obtained, it showed that the animal on high-cholesterol diet had increased TC, increased LDL-C, and decreased HDL-C when compared to the rats on the normal diet. When high-cholesterol diet was coadministered with $400 \mathrm{mg} / \mathrm{kg}$ of BP extracts, the increased levels of TC and LDL-C had shown significant reduction while decreased levels of HDL-C has shown significant elevation. This indicates that the ability of $400 \mathrm{mg} / \mathrm{kg} B P R$ extract in preventing the incensement seen in lipid profile under experimentally induced hypercholesterolemia. From previous studies, it showed that flavonoids have the ability to reduce LDL-C and increase HDL-C in hypercholesterolemia-induced rats [9]. Hence, in this study, flavonoids presence in $B P R$ extract might be the reason for reducing TC, LDL-C, and increasing HDL-C in $400 \mathrm{mg} / \mathrm{kg}$ treated rats.

\section{CONCLUSION}

In conclusion, the findings of the study revealed that the BPR extract at a dose of $200 \mathrm{mg} / \mathrm{kg}$ does not possess antihyperlipidemia properties, while at a dose of $400 \mathrm{mg} / \mathrm{kg}$, it does possess antihyperlipidemia properties when compared with the positive control group. The results of the data have supported the presence of antihyperlipidemia effect of $B P R$ extract at a dose of $400 \mathrm{mg} / \mathrm{kg}$.

\section{ACKNOWLEDGMENT}

The author would like to thank Professor Tan Sri Dato' Wira, Dr Mohd Shukri Ab Yajid, President, Management \& Science University, for providing financial support to carry out the research project and publish.

\section{REFERENCES}

1. Sudha SS, Karthic R, Naveen, Rengaramanujam J. Anti hyperlipidemic activity of Spirulina platensis in triton $\mathrm{x}-100$ induced hyperlipidemic rats. Hygeia J D Med 2011;3:32-7.

2. Katzung BG, Masters SB, Trevor AJ. Basic and Clinical Pharmacology. New York: McGraw-Hill Medical; 2012

3. Girija K, Lakshman K. Anti-hyperlipidemic activity of methanol extracts of three plants of Amaranthus in triton-WR 1339 induced hyperlipidemic rats. Asian Pac J Trop Biomed 2011;1:S62-5.

4. Subramaniam S, Ramachandran S, Uthrapathi S, Gnamanickam VR, Dubey GP. Anti-hyperlipidemic and antioxidant potential of different fractions of Terminalia arjuna roxb. Bark against PX- 407 induced hyperlipidemia. Indian J Exp Biol 2011;49:282-8.

5. Rao BS, Srinivasa B, Desu R, Saileela C. Anti-hyperlipidemic activity of methanolic extract of Rhinacanthus nasutus. Int J Res Pharm Chem 2013;3:708-11

6. Cheenpracha S, Karalai C, Ponglimanont C, Subhadhirasakul S, Tewtrakul S. Anti-HIV-1 protease activity of compounds from Boesenbergia pandurata. Bioorg Med Chem 2006;14:1710-4.

7. Abdelwahab SI, Mohan S, Abdulla MA, Sukari MA, Abdul AB, Taha MM, et al. The methanolic extract of Boesenbergia rotunda (L.) mansf. And its major compound pinostrobin induces anti-ulcerogenic property in vivo: Possible involvement of indirect antioxidant action. J Ethnopharmacol 2011;137:963-70.

8. Balasubramanian MN, Muralidharan P, Balamurugan G. Anti hyperlipidemic activity of Pedalium murex (linn.) fruits on high fat diet fed rats. Int J Pharmacol 2008;4:310-3.

9. Dhulasavant V, Shinde S, Pawar M, Naikwade NS. Antihyperlipidemic activity of Cinnamomum tamala nees. on high cholesterol diet induced hyperlipidemia. Int J PharmTech Res 2010;2:2517-21 